\title{
HYDROGELS PENETRATION AND SORPTION PROPERTIES IN THE SUBSTANCES RELEASE CONTROLLED PROCESSES
}

\author{
Lviv Polytechnic National University \\ 12, Bandera str., 79013 Lviv, Ukraine \\ vskorohoda@yahoo.com
}

Received: J anuary 20, 2009

(c) Skorokhoda V., Semenyuk N., Melnyk J., Suberlyak O. 2009

\begin{abstract}
The crosslinked copolymers of 2-hydroxyethyl methacrylate with polyvinylpyrrolidone as granules and membranes have been synthesized and their penetration and sorption-desorption properties have been investigated. The model of mass-transfer from the solid soluble surface through the hydrogel shell has been suggested. The developed materials are able to create encapsulated and granular polymer forms of drugs prolonged release.
\end{abstract}

Key words: hydrogel, polyvinylpyrrolidone, 2-hydroxyethyl methacrylate, sorption, penetration.

\section{Introduction}

The development of polymeric systems of drugs prolonged and directed release is one of the main directions in pharmaceutical and medical branches. Such systems allow to transfer a medical substance directly to the active medium as well as to reduce essentially its disposable therapeutic doze [1]. Polymeric hydrogel carriers based on crosslinked copolymers of polyvinylpyrrolidone (PVP) with methacrylic esters, 2-hydroxyethyl methacrylate (HEMA) namely, are used for above-mentioned purposes. They are able to swell in water and physiological solutions but are insoluble in such media and have controlled penetration and sorption-desorption properties due to the presence of different functional groups in their structures [2].

\section{Experimental}

HEMA was purified by a vacuum distillation (residual pressure $130 \mathrm{~N} / \mathrm{m}^{2}, T_{\text {boil }}=351 \mathrm{~K}$ ). Highly purified PVP with the molecular mass $28 \cdot 10^{3}$ was used for polymerization. The reaction mixture solubility parameter ( $\delta$ ) was calculated from the solubility parameters of individual components $\delta_{i}[3]$, according to the equation:

$$
\delta=\left(\Sigma V_{i} \delta_{i}\right)^{1 / 2}
$$

where $V_{i}$ is the volume fraction of the $i^{\text {th }}$ component; $\delta_{i}$ is the solubility parameter of the $i^{\text {th }}$ component.

The hydrogel membranes for parameters investigation of mass-transfer from the solid phase of model substances and medical forms were formed via polymerization of polymer-monomer compositions between two glass or fluoroplastic plates as films with different thickness; for capsulation of the real medical forms - via polymerization coating in the boiling bed reactor [4]. Hydrogel granule particles were obtained via suspension polymerization based on the technology described in [5].

Polymerization kinetics, composition and structural parameters of copolymer networks were investigated by the techniques described in $[4,6]$ and polymers permeability - by the technique offered by Karelin [7]. Methylene-blue (MB) was quantitatively determined by KFK-3 photocolorimeter using the light-filter with $\lambda=420 \mathrm{~nm}$.

\section{Results and Discussion}

At the Department of Chemical Technology of Plastics Processing of Lviv Polytechnic National University there are two researching directions concerning development of drugs prolonged release systems based on polymeric hydrogels. The first direction is a capsulation of solid parts by polymeric hydrogel shell. The second one is development of granular forms operated by the following scheme: drug sorption by polymer - drug release in the organism. The technological aspects of both types of copolymers obtained via radical polymerization in the presence of peroxide initiators are considered in [4] and [5], respectively.

Application of PVP-FeSO $\mathrm{P}_{4}$ complex as an initiating system instead of potassium persulphate allows to shorten synthesis time and considerably reduce the synthesis temperature (Table 1). The content of residual monomer 
Effect of composition contents and forming modes on the reaction completeness degree*

\begin{tabular}{|c|c|c|c|c|c|c|}
\hline \multirow{2}{*}{ No. } & \multicolumn{7}{|c|}{ Mixture composition, mass parts } & \multirow{2}{*}{ Forming mode } & \multirow{2}{*}{$M_{\text {rem }}, \%$} \\
\cline { 2 - 5 } & HEMA & PVP & $\mathrm{H}_{2} \mathrm{O}$ & Initiator (catalyst) & & 1.5 \\
\hline 1. & 90 & 10 & 100 & $0.3 \% \mathrm{PPS}$ & $333 \mathrm{~K}-2 \mathrm{~h} ; 343 \mathrm{~K}-2 \mathrm{~h}$ & 2.0 \\
\hline 2. & 80 & 20 & 100 & $0.3 \% \mathrm{PPS}$ & $333 \mathrm{~K}-2 \mathrm{~h} ; 343 \mathrm{~K}-2 \mathrm{~h}$ & 2.5 \\
\hline 3. & 80 & 20 & 50 & $0.05 \% \mathrm{FeSO}_{4}$ & $278 \mathrm{~K}-1 \mathrm{~h}$ & 1.0 \\
\hline 4. & 80 & 20 & 100 & $0.05 \% \mathrm{FeSO}_{4}$ & $323 \mathrm{~K}-0.5 \mathrm{~h}$ & 1.0 \\
\hline 5. & 80 & 20 & 300 & $0.05 \% \mathrm{FeSO}_{4}$ & $323 \mathrm{~K}-0.5 \mathrm{~h}$ & 2.0 \\
\hline 6. & 70 & 30 & 100 & $0.05 \% \mathrm{FeSO}_{4}$ & $323 \mathrm{~K}-0.5 \mathrm{~h}$ & 2 \\
\hline
\end{tabular}

* - by content of residual monomer $M_{r e m}$; PPS - potassium persulphate

Table 2

Graft parameters and copolymers composition

\begin{tabular}{|c|c|c|c|c|c|c|}
\hline \multirow{2}{*}{ No. } & \multicolumn{2}{|c|}{ Mixture composition, mass parts } & \multirow{2}{*}{$\begin{array}{l}f, \\
\%\end{array}$} & \multirow{2}{*}{$\begin{array}{l}P, \\
\%\end{array}$} & \multicolumn{2}{|c|}{ Copolymer composition, mass parts } \\
\hline & HEMA & PVP & & & polyHEMA & PVP \\
\hline 1. & 90 & 10 & 53 & 5 & 94.7 & 5.3 \\
\hline 2. & 80 & 20 & 52 & 10 & 89.6 & 10.4 \\
\hline $3 *$ & 80 & 20 & 53 & 11 & 89.4 & 10.6 \\
\hline $4 * *$. & 80 & 20 & 49 & 10 & 90.2 & 9.8 \\
\hline 5. & 70 & 30 & 38 & 11 & 88.6 & 11.4 \\
\hline
\end{tabular}

$f$ - PVP graft effectiveness; $P$ - graft degree; $*$ - for T $=343 \mathrm{~K} ; * *-$ for $\mathrm{T}=353 \mathrm{~K}$

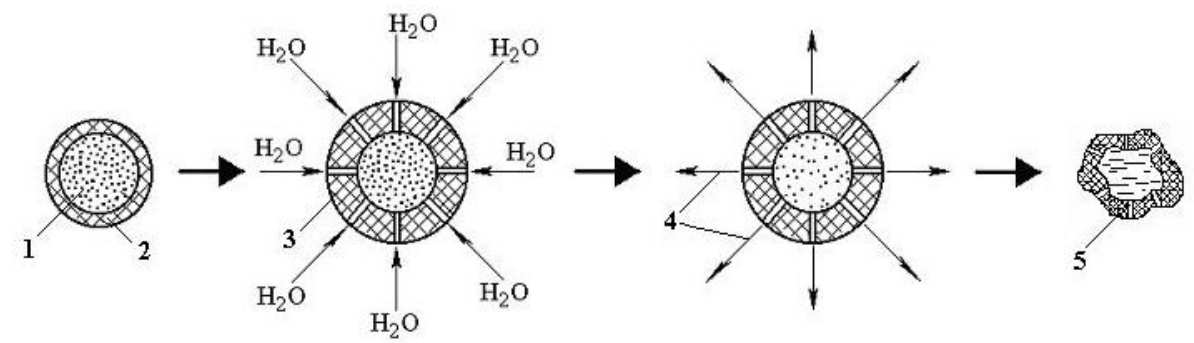

Fig. 1. The scheme of components transfer from capsulated particles: drug (1); solid polymer shell (2); swelled crosslinked gel (3); drug prolonged release (4) and spent capsule (5)

depending on the synthesis mode is $0.5-2.5$ mass parts. Since it is expected to use the obtained polymers in medical practice, then polymer washing stage in the technological scheme necessary for the removal of unreacted monomer should be foreseen [4].

Synthesized copolymers are crosslinked compounds consisting of PVP macromolecules with grafted polyHEMA chains. They have functional groups with different polarities: $\mathrm{C}=\mathrm{O}$ and $-\mathrm{OH}$ groups of monomer and $\mathrm{N}-\mathrm{C}=\mathrm{O}$ group of PVP. Moreover, in aqueous media PVP chain links may exist in ketonic forms or forms with cationic nitrogen [8]. The hydrogel structural parameters and composition may be directly changed by synthesis conditions (Table 2) [9]. All above mentioned factors, of course, will affect the sorption and diffusive-transfer properties of synthesized copolymers.

Copolymers synthesized in the form of membranes are effective capsulated agents of solid drugs. In a dry state while storing they act as a protective capsule but while operating they are able to swell in the physiological solution and become permeable. The mechanism of components transfer from capsulated particles is following: copolymer swelling, molecular diffusion inside the capsule, mass transfer through the polymeric membrane and mass delivery into the ambient solution (Fig. 1).

The spent capsule is removed out of the organism by natural way without the organism damage.

In order to forecast the duration of drug release from the capsulated particle, as well as its final concentration in the solution, the model of mass transfer from the globular particle which is shelled with the polymeric hydrogel has been developed (Fig. 2).

The thickness of the hydrogel shell while swelling will be changed by the following dependence:

$$
\delta=\delta_{n}\left[1+\alpha_{\max }\left(1-e^{-K t}\right)\right]
$$


where $\delta_{n}, \delta$ - thickness of dry and swelled hydrogel shell, $\mathrm{m} ; t$ - swelling time, $\mathrm{s} ; K$ - swelling rate constant, $\mathrm{s}^{-1}$; $\alpha_{\max }-$ maximum value of swelling coefficient.

Compound concentration $c$ in the solution is:

$$
\mathrm{c}=\frac{4 \pi \cdot\left(\rho_{\mathrm{T}}-c_{\mathrm{s}}\right)\left(\mathrm{r}^{3}-3 \mathrm{Rr}^{2}+3 \mathrm{Rr}^{2}\right)}{3 \mathrm{~W}}
$$

If $r=R$, then

$$
\mathrm{c}=\mathrm{c}_{\max }=\frac{4 \pi \cdot\left(\rho_{\mathrm{T}}-\mathrm{c}_{\mathrm{s}}\right) \mathrm{R}^{3}}{3 \mathrm{~W}}
$$

The change of particle radius and mass at $\delta<<R$ equals to:

$$
\begin{aligned}
& \frac{\mathrm{dr}}{\mathrm{dt}}=\frac{\left(\mathrm{c}_{\mathrm{s}}-\mathrm{c}\right)}{\left.\rho_{\mathrm{T}}\left(\beta^{-1}+\mathrm{rD}_{1}^{-1}+\delta \mathrm{D}_{2}^{-1}\right)\right]} \\
& \frac{-\mathrm{dM}}{\mathrm{dt}}=\frac{4 \pi \cdot \mathrm{R}^{2}\left(\mathrm{c}_{\mathrm{s}}-\mathrm{c}\right)}{\left(\beta^{-1}+\mathrm{rD}_{1}^{-1}+\delta \mathrm{D}_{2}^{-1}\right)}
\end{aligned}
$$

where $M$ - particle mass, $\mathrm{kg} ; D_{1}, D_{2}$ - diffusion coefficients in the solution inside the capsule and polymer, respectively, $\mathrm{m}^{2} / \mathrm{s} ; R$-particle radius, $m ; \rho_{\mathrm{T}}$ - solid particle density, $\mathrm{kg} / \mathrm{m}^{3} ; c_{s}$ - concentration of the substance over the particle surface, $\mathrm{kg} / \mathrm{m}^{3} ; r$-reduction of particle radius; $\beta$ - mass-transfer coefficient, $\mathrm{m} / \mathrm{s} ; W$ - liquid volume, $\mathrm{m}^{3}$.

The mathematic model and its testing in details are described in [10]. Maple v6.01 mathematical pack was used for the model numerical realization. The obtained results allow to forecast the duration of drug removal from the particle, as well as its final concentration in the solution.

Investigated polymers have also been used for the development of drug delivery systems of another type, so called granular copolymers. Sorption properties of such copolymers are determined by net structural parameters and the presence of different functional groups in the copolymer.

MB and carbamazine sorption and desorption processes were examined with the purpose of establishing the suitability of the synthesized copolymer materials as granules for the drug delivery systems creation. The comparative researches of $\mathrm{MB}$ sorption by polymeric

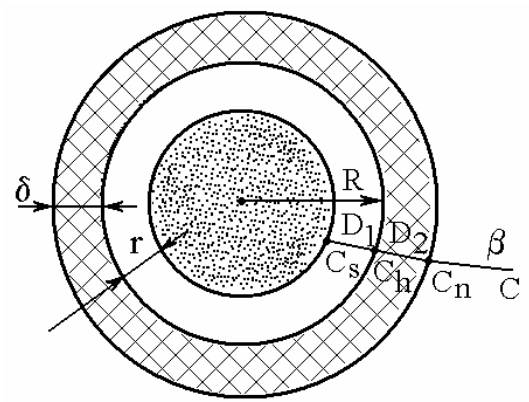

Fig. 2. The scheme of mass transfer from the solid particle with the hydrogel shell

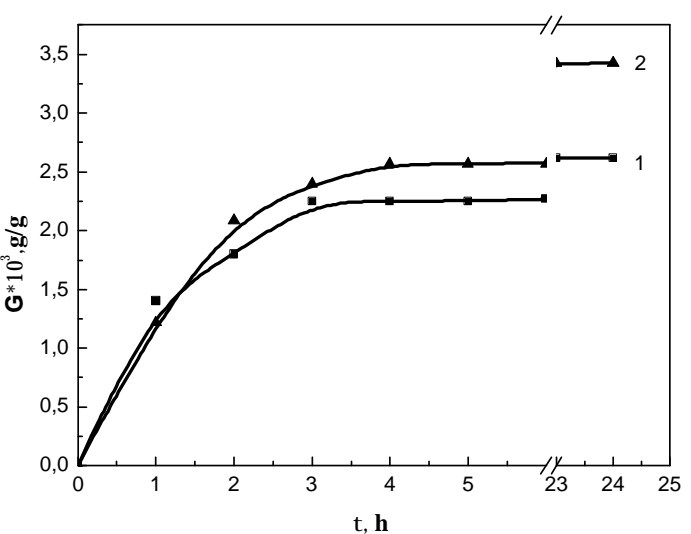

Fig. 3. Kinetic curves of MB sorption by the polymers: PVP-gr-polyHEMA (1); polyHEMA (2).

Particles average sizes, $d_{n}$, mm: $0.47(P D I=1.24)(1)$; $0.90(P D I=1.27)(2)$

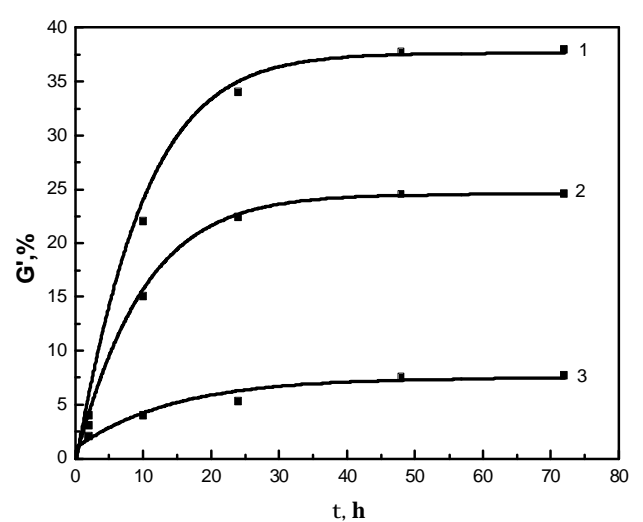

Fig. 4. Effect of $\mathrm{pH}$ environment on kinetics of $\mathrm{MB}$ desorption $\left(G^{\prime}\right)$ by the granular copolymers PVP-gr-polyHEMA. pH: 4 (1); 7 (2); 9 (3)

particles based on polyHEMA and HEMA-PVP copolymers were conducted in a neutral environment (Fig. 3). One can see from experimental results that the dye main part is sorbed during the first three hours, later the process proceeds slowly and the kinetic curve gradually goes out on saturation. Moreover, the sorption ability of homopolymer particles, even with greater sizes, is higher compared with copolymers.

It is known [11] that in the MB sorption processes the presence of hydroxyl and carboxyl groups on the sorbent surface plays the significant role. The relative amount of such groups in polyHEMA is higher compared with that in the copolymer owing to the stronger electrostatic interaction between such groups and $\mathrm{MB}$ cation $\left(=\mathrm{N}^{+}=\left(\mathrm{CH}_{3}\right)_{2}\right)$. The PVP links of the copolymer in the aqueous medium can exist both in the keto-form, and the form containing the nitrogenous cation. Although the part of the latter ones is insignificant [8], it is the reason of less sorption ability in relation to $\mathrm{MB}$.

Rate and value of $\mathrm{MB}$ desorption ( $\left.\mathrm{G}^{\prime}\right)$ by copolymer spheres depend on the $\mathrm{pH}$ medium (Fig. 4). The most intensive $\mathrm{MB}$ release takes place in the acid medium, in 


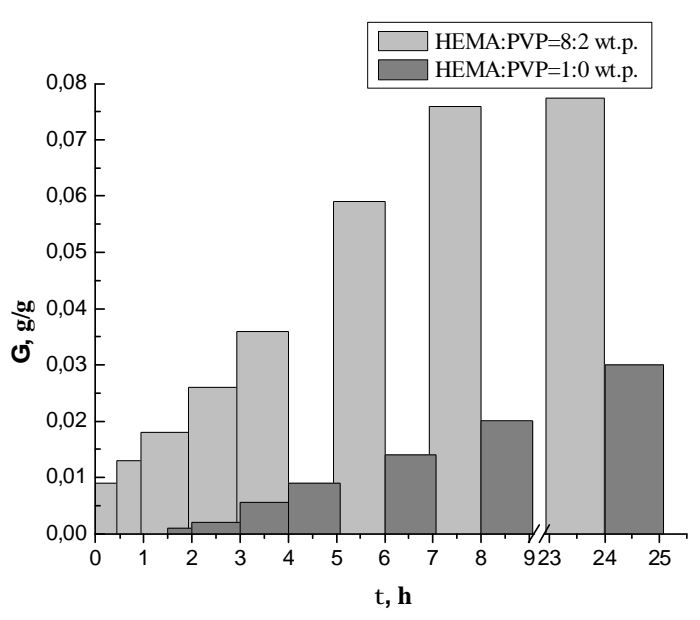

Fig. 5. Effect of polymeric carriers nature on the carbamazine sorption

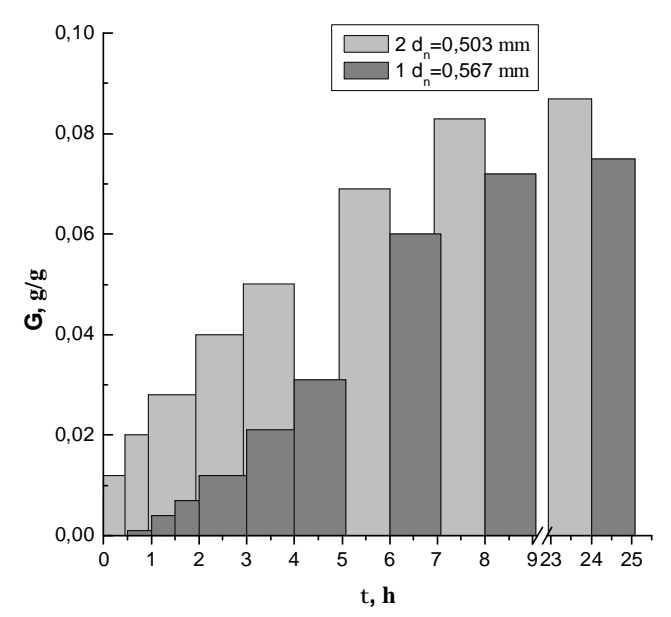

Fig. 6. Effect of solubility parameter $d$ on the copolymers sorption properties. [HEMA]:[PVP] $=8: 2$ mass parts; $d=41.9(1)$ and $44.5(\mathrm{MPa})^{1 / 2}(2)$

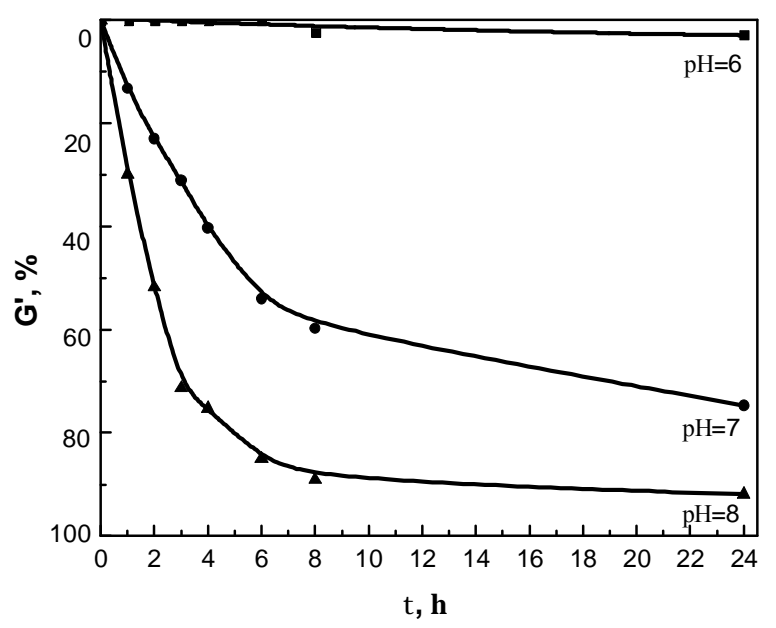

Fig. 7. The effect of $\mathrm{pH}$ environment on kinetics of carbamazine desorption $[$ HEMA]:[PVP] $=8: 2$ mass parts addition the greater value of the boundary desorption is achieved. Obviously, in such a case a formed complex between functional groups of MB and copolymers is destroyed resulting in a greater rate and maximum value of desorption.

In the case of carbamazine, which contains three carboxyl and one hydroxyl groups in its composition, HEMA and PVP copolymers have the greater sorption ability (Fig. 5), which is 2.5 times higher than that for polyHEMA particles.

The introduction of PVP links into the copolymer composition considerably increases the sorption speed and the boundary amount of the sorbed drug. Thus the adjustment of polyHEMA and PVP links correlation enables to change the sorption properties of copolymers in the necessary direction.

It is possible to affect the sorption ability of polymer particles of the same composition by means of their sizes which are capable for regulation by the change of mixing intensity and solubility parameter of the initial compositions $\delta$ (Fig. 6).

The obtained results show that particles of the greater size naturally sorb the carbamazine with the less rate due to their less specific surface. Hence we may conclude that carbamazine sorption takes place mostly over the surface and in the resurfaced layers of granules.

The important task of this work was to examine the effect of $\mathrm{pH}$ environment on desorption properties of synthesized granular copolymers (Fig. 7). The subacid medium simulated the stomach medium, subalkali one the intestines medium. One can see from the obtained results that medium $\mathrm{pH}$ substantially affects the carbamazine desorption. In a subacid medium the latter one is practically not extracted from polymer particles. It is very important, because in such a case the carbamazine will not irritate the stomach surface. But in neutral and subalkali media carbamazine is segregated by doses, therapeutically sufficient for medical aims. Synthesized copolymers are distinguished by chemical stability in subalkali and subacid media and withstand sterilization in an autoclave.

\section{Conclusions}

The obtained results offer the challenge for the application of the synthesized hydrogel polymers as the membranes and granules for the creation of directional and controlled drug release systems, carriers for chromatographic processes, ion-exchange, biospecific and gel-penetrating chromatography in particular, including protein separation from blood plasma and for immunological investigations. 


\section{References}

[1] Grigoryanc I. and Trikhanova G.: Polymernye systemy upravlyaemogo vydeleniya veshchestv, Khimiya, Moskwa 1984.

[2] Skorokhoda V., Semenyuk N. and Suberlyak O.: Polimernyi Zh., 2006, 2, 155.

[3] Horak D., Semenyuk N. and Lednicky F. J. Polym. Sci., 2003, 41, 1848.

[4] Suberlyak O., Mel'nyk J. and Skorokhoda V.: Khim. Promyslovist' Ukrainy, 2008, 2, 29.

[5] Skorokhoda V., Semenyuk N. and Suberlyak O.: Voprosy Khimii i Khim. Technologii, 2006, 3, 67.

[6] Suberlyak O., Skorokhoda V. and Semenyuk N.: Eng. Biomater., 2007, 63-64, 14.

[7] Dubyaga V., Perepechkin L. and Katalevskyi E.: Polymernye membrany. Khimiya, Moskwa 1984.

[8] Marutamutu M.: J. Polym. Sci.,1984, 10, 569.

[9] Skorokhoda V., Semenyuk N. and Suberlyak O.: Voprosy Khimii i Khim. Tehnologii, 2004, 3, 88.
[10] Demchuk I., Skorokhoda V. and Slobodyan V.: Ekotechnologii i Resursozberezhenie, 2003, 1, 70.

[11] Mamleeva N., Pisareva R. and Lunin V.: Zh. Fizicheskoi Khimii, 1994, 4, 671.

\section{ПРОНИКНІСТЬ ТА СОРБЦИЙНІ ВЛАСТИВОСТІ ГІДРОГЕЛІВ У ПРОЦЕСАХ КОНТРОЛЬОВАНОГО ВИВІЛЬНЕННЯ РЕЧОВИН}

\footnotetext{
Анотація.Синтезовано рідкоструктуровані кополімери 2-гідроксіетилметакрилатуз полівінілпіролідоном у вигляді гранул та мембран і досліджено їхню проникність та сорбиійно-десорбиійні властивості. Запропоновано модель масоперенесення з твердої розчинної поверхні через гідрогелеву оболонку. Підтверджена придатність розроблених матеріалів для створення на їхній основі капсульованих та гранульних полімерних форм пролонгованого вивільнення ліків.

Ключові слова: гідрогель, полівінілпіролідон,
} 2-гідроксіетилметакрилат, сорбиія, проникність. 